\title{
Civic Education as Education for Peace in the Context of Serbia's 2000 Democratic Revolution
}

\author{
Sanja Djerasimovic
}

\begin{abstract}
The introduction of civic education in Serbia in 2001 marked a beginning of an allencompassing reform that set the tone for future changes designed to support the country's democratization. This article draws on documentary and elite interview data to unpack the conceptualization of this policy, revealing it to be a multi-level positioning exercise in the national and international political space. It argues that, by using favorable political and international policy conditions, Serbian policymakers created a version of civic education that significantly drew on grassroots peace education programs developed during the 1990s, recognizing the priority of needs in building a democratic society. The latter offered Serbian policymakers agency in the context of what critical literature perceives as a transfer/imposition of policies in societies facing "Westernization."
\end{abstract}

Keywords civic education, peace education, post-communist reform, policy transfer, policy as discourse

\section{Introduction}

In 2000, Serbia underwent what has since in public discourse been referred to as a "democratic revolution." A communist country (as a part of the Yugoslavian federation) from 1945 onwards, it began transitioning to a state of multi-party politics and a market economy in 1990, concurrently with other formerly communist European countries. However, whilst most other countries continued on the path of democratization and liberalization, Serbia entered what would become a decade spent under the authoritarian regime of Slobodan Milošević. In addition to the regime's illiberal governance, the country experienced extreme poverty, devastation of the economy, international isolation, and involvement in civil wars in Bosnia and Croatia in the early 1990s, and a military intervention in Kosovo that ended in NATO's (North Atlantic Treaty Organization) bombing of 
Serbia in 1999. Thus, when the new democratic government was finally installed in 2001, the urgency to "catch up" with the rest of the formerly communist Europe led to swiftly instigated reforms across all sectors of society. In education, the first, and one of the more symbolic steps of the early reform, was the decision to introduce civic education in primary and secondary schools. In this article, I use the account of this education policy development to interrogate the processes of educational decision-making at a nation-state level in the context of the country's opening and reconstruction, and significant dependence on foreign investment, as well as, separately, examine the content of the policy and make observations on the nature and purpose of civic education.

The article will demonstrate how, using favorable economic and political conditions created in the wake of the authoritarian regime's demise and the country's accelerated transition to democracy, the then educational policymakers used the malleability of the concept of civic education to create their version of the subject. This example of the process of policymaking is intended to complicate what is in post-communist literature often described as a transfer, or rather adoption of, education policy as dictated by supranational organizations and/or Western-centric educational narratives. ${ }^{1}$ Serbian policy actors, it will be shown, made up in part from the progressive educators who had devised and delivered numerous peace education programs in Serbia during the 1990s, relied substantively on locally generated ideas on the importance of emotional expression, tolerance, and community, as the basis of developing the idea of citizenship-fostered-through-education. In this, the article argues, Serbia's early version of civic education ended up sharing much of the precepts of peace education, and in some ways anticipated a version of post-national, peacefostering citizenship propagated through the contemporary global citizenship agenda (UNESCO 2015a; 2015b).

The next section offers a brief introduction of the historical context of Serbia's 2000 democratic revolution, and the country's socio-political positioning in the international space, thus setting the stage for the first proper post-communist educational reform that took place some ten years after reforms that swept through Europe following the fall of the Berlin Wall. It explains the relevance of this belated nature of the reform both contextually and conceptually, as well as presenting the circumstances and political significance of starting the reform with the introduction of civic education. The following section then further elaborates on Serbia's 2001 reform in the wider framework of post-communist reform, and explains the international and supranational civic education policy setting in which it started. This is followed by the outline of the research design and the findings about the nature and meaning of the Serbian civic education policy, as an example of the use of discursive capital in negotiating and navigating the national and international policy space, and the then recognized importance of aligning the processes of building democratic citizenship and fostering positive 
peace (Galtung 2011). The article concludes with thoughts on the contemporary nature of global civic education, the relationship between democracy and positive peace, and outlines possible directions for further study.

\section{Serbia at the Beginning of the Twenty-First Century}

In 2000, following the final in the line of massive public protests against fraudulent elections, the decade long regime of Slobodan Milošević was brought to an end in Serbia's "democratic revolution." The 1990-2000 regime has been defined as "competitive authoritarianism" in the political theory literature (Levitsky and Way 2005), a version of a semi-authoritarian regime in which opposition existed and was very active, but was continually suppressed and oppressed. Elections were regularly held and the opposition won seats in the parliament, but through various degrees of fraud were never allowed victory. This political system distinction is important as it allows the reader to appreciate the existence of spaces for subversive action during the ten-year period, spaces in which the future education policy actors moved, collaborated, and created.

Serbia's turn-of-the-century democratic revolution also marked the beginning of the country's first modern democracy. Although Serbia experienced multiparty politics as early as the nineteenth century (see Corovic 2004), both as an independent country, and, after World War I, as a part of the Kingdom of Yugoslavia, this never really blossomed into a full democracy, and its development was further halted by the institution of the communist system after World War II. This system experienced dissolution together with other communist systems in Europe, and by 1990 multi-party politics entered the scene once more. It is important to stress that communist Yugoslavia, one of the founding members of the Non-Aligned Movement in the 1960s, had enjoyed a much more liberal experience of communism than the members of the Eastern Bloc, as well as free global exchange of people and ideas as a result of its policy of neutrality in the Cold War, and was predicted by the commentators to be among the first countries to transition from state socialism to parliamentary democracy and a liberal economy (King 2000). However, the aftermath of the political-ideological collapse of the communist system also saw a dissolution of Yugoslavia as a federation of six republics (and two autonomous provinces), a violent disintegration accompanied by civil wars in the former republics of Bosnia and Herzegovina and Croatia, and the NATO bombing of Serbia due to its interventions in the autonomous, Albanian-majority Kosovo, which would also subsequently secede in 2006, and assume as yet unresolved status with(in) Serbia.

This "interruption" in the development of a modern democratic system of government had been referred to in Serbian public discourse as a "belated" or even "retarded" transition, as the countries formerly belonging to the 
post-communist bloc (problematic though such nomenclature and implicit homogenization may be) journeyed on in their quest to democratization and Europeanization, with the first Eastern European countries achieving the goal of "returning back to Europe" (Birzea 1994) by entering the European Union (EU) in 2004. Once Serbia's new democratic government was installed in 2001, the government proclaimed the processes of democratization, modernization, and Europeanization the goals of the overarching reform, including that of education, and pronounced education for democracy, of which civic education was to be one aspect, one of the chief drivers of these processes (Ministry of Education and Sport Republic of Serbia 2002). The introduction of a separate subject as a part of the multi-pronged drive towards building education for democratic citizenship (other aspects included a more democratic pedagogy in the system in which the transmission of knowledge had been the primary form of teaching and learning, and a more democratic system of school governance) had been planned from the very beginning, as evidenced in key policy documents. However, the prompt introduction of the subject of civic education, less than a year into the new government's mandate, was perhaps provoked by an unexpected development in the form of a concession that the new government decided to offer to the Serbian Orthodox Church, a powerful ally, and allow the reintroduction of religious education in primary and secondary school curricula. Civic education was then offered as an alternative to religious education, and students in Serbia have since been choosing between one of these two "compulsory electives."

This opposition between religious and civic education is of no small significance, as it both symbolizes and fosters the polarization in Serbian society between the "traditional" and the "modern," as well as promoting the idea of citizenship that is divorced from its roots in the national and the religious. The latter, as I will discuss below, has been perhaps one of the unintended consequences of building education for democratic citizenship on the foundations of peace programs, which, whilst important for connecting ideas of (positive) peace and democracy, in the context of the aftermath of ethnic conflict, inevitably eschewed the notions of national, ethnic, and religious belonging. What Serbian policymakers did achieve through this pragmatic as well as ideological handling of the issue was to use the then relevant European and global civic education initiatives as sources of both discursive and economic support to create a significantly self-referential (Schriewer 2003) version of a subject that could have otherwise become an example of policy transfer, colonized by an externally created educational discourse.

\section{Serbia’s 2001 Reform and Civic Education Policy in Context}

As mentioned above, by the time Serbia began transitioning to democracy in 
2000, a decade had passed since the dissolution of communism across Europe, and accompanying scholarship's attempt to explain and predict the various new (especially in the light of the Soviet Union's break-up) nation states' trajectories, including in education. Most of these early attempts at post-communist models of education (see Birzea 1994, 1996; McLeish and Phillips 1998) were fairly linear in nature and assumed, if not a straightforward, then almost inevitable, transition from communism to democracy, with varying, contextually dependent degrees of complication and obstruction. Only later did it become clear that circularity, regression, and hybridity might indeed be possible. Some political theorists pointed out that these newly democratized states would develop systems of their own that could not follow the Western model created under very specific historic political and economic circumstances (Offe 1991; Blokker 2005), or that they would eventually achieve "democratization without decommunization" (Mungiu-Pippidi 2006). In the meantime, in education, authors began arguing for transformation in place of teleological transition (Silova 2010), and emphasized the need for scholars to explore these transformations in their own right, instead of judging the success with which the transition to a pre-determined state modelled after Western examples has been achieved.

Partly, this scepticism and criticism came from the undesirable effects of the modernizing, homogenizing paradigm assumed by international funding agencies such as the World Bank (Klees 2002), as well as the more soft power-led international organizations' missions to deliver education of a certain kind and quality to systems that were ill-prepared for these transnational programs, but that accepted them through various models of policy transfer either because of the economic support that came with them or the expectation of the superiority of these solutions to any that would have been locally produced. Later, authors such as Silova and Steiner-Khamsi (Silova and Steiner-Khamsi 2008; SteinerKhamsi and Quist 2000) coined the concept of "transfer of discourse" (rather than policy), pointing out that post-communist countries were usually only adopting the discourse associated with the policy for reasons of signalling that they were on the "correct" course, ${ }^{2}$ but that the practices would have normally either remained unchanged or become layered with new practices, creating hybrid forms, but hardly leading to the Westernization of the post-communist classroom.

The case of the Serbian civic education policy could have easily been described-and thus dismissed, obscuring the wealth of local agency and complexity of local-international interaction described below-as a case of discourse transfer. At the time of its introduction in Serbian schools, civic education was experiencing considerable popularity concurrent with, and to some degree, following from, late-modern concerns about the direction and purpose of education in the century characterized by globalization, marketization, and multi-culturalism (Turnbull 2002; Forrester 2003; Dahlin 2010), and the worries over prevailing apathy, a lack of trust in democratic institutions, and increased 
individualization, xenophobia, and racism (Forrester 2003). Civic education has been imagined as holding the potential to imbue students with values, knowledge, and practices needed to make them capable of actively participating in an ongoing process that is democracy (Crick 2007). Designed to provide civic and political socialization, the subject of civic education has differed from one country to the next, depending on the particular needs of civil society, and the social, political, and educational context and tradition-from a greater focus on political education in Germany, to primarily values- and ethics-based civic education in Portugal, for example (Birzea 2004). But there were three broad domains of civic education that appeared across national policies: national identity, democracy, and social diversity and cohesion (Steiner-Khamsi, Torney-Purta, and Schwille 2002).

Since the end of the last century, similar ideas have been strengthened and internationally promoted through the work of organizations such as the Council of Europe, with its Education for Democratic Citizenship initiative (its second phase took place between 2001 and 2004), and the United Nations Education, Scientific and Cultural Organization (UNESCO)-promoted decade of human rights education (1995-2004). The idea(l) of active social and political commitment was designed in such a way so as to encompass its cognitive (knowledge of legal and political systems and frameworks), affective (internalization of the "right" values), and social (knowledge of practicing democracy in all spheres of life and every circumstances) aspects (Duerr 2000). These initiatives attempted thus to incorporate diverse conceptualizations of civic education (here used as a broad umbrella term, similarly to how Levinson (2014) uses it interchangeably with citizen education), from a "thinner," knowledgebased tradition of civics to a "thicker," value-based tradition of citizenship education (McLaughlin 1992).

These initiatives that saturated the transnational educational space, combined with the expectations specific to the nation state, and oft associated with financial aid, created fertile ground for the civic education policy (discourse) to be transferred from the international organizations' guidelines into national policy documents, particularly in the context of post-war, postcommunist transition and (re)construction. In most other post-communist countries, some form of civic education had existed as a subject pre-1989, and was one of the first subjects to be removed from the curriculum in the post-1989 deideologization, as it had been designed to help foster a kind of citizen desired by that political system, and usually imbued with Marxist and socialist ideas. Despite the existence, even during the communist era, of democratic practices in education such as equal provision of education to all (see Perry 2012), or youth movements that were rather close in idea and nature to the cohesive, communityparticipating ideal proffered by programs such as Education for Democratic Citizenship, post-communist governments' practice of developing "new" civic 
education usually very often included addressing their "democratic deficit" (Nicoll et al. 2013) helped by Western (mostly American) educators and NGOs dedicated to education for democracy (Vaillant 2001; Buk-Berge 2006). In fact, some critics of the "democracy aid" agenda have pointed out that civic education tended to be a part of the wholesale democracy packages offered to the post-communist countries (see Carothers 2009).

In Serbia too, the third sector that flourished during the 1990s and especially after the revolution, was funded in great part by international donorsoccasionally international organizations, occasionally the foreign aid agencies discussed by Carothers (ibid.) - and there were distinct channels through which imported programs could have ended up forming the core of Serbia's civic education. Given the national political elite's hurry to return to the course from which they felt the country had been side-tracked by a ten-year delay, perhaps it was to be expected that international solutions were to be quickly adopted and adapted. However, the ten-year delay did not happen in a vacuum. The processes and effects of the politically manipulated nationalism during the 1990s created among Serbian educators a sense of clear normative direction for democratic citizenship post-2000, and one that was not necessarily simply a negation of authoritarianism. At the same time, Serbian educators had the time and the opportunity to observe other post-communist countries' experiences of reform, and use these experiences to their advantage in preparing the ground for the reform of the Serbian system. With that, Serbian post-2000 educational policy elite were able to exercise a significant amount of agency when faced with international donors and transnational educational discourses.

\section{Project Details}

The project on which the article draws was delivered through the author's doctoral research conducted between 2011 and 2014, guided by questions about the origin of the civic education policy and its relationship to the wider reform discourse in post-2000 Serbia. The fieldwork consisted of nineteen elite interviews with various figures in Serbia (and one in the United Kingdom) who were identified through previous research as relevant policy actors. The focus on elite interviews was determined by a decision to examine the process of policy development only, and reserve the research of policy reception and "on the ground" implementation for a later study. The group of interviewees included the Minister for Education in the 2001-2003 government, his deputy, key civic education curriculum developers and leaders of the Serbian program for education for democratic citizenship (EDC), members of international funding agencies, members of Serbian and international civic education NGOs, as well as the most prominent critics of the reform. Semi-structured interviews were conducted with all of them, all but one 
in Serbian, transcribed and analyzed in the original language. In addition to the interview data, the research project involved a large corpus of documentary data that was perceived as of significance in constructing the civic education policy discourse. Documents analyzed were the reform White Paper in both its Serbian and English versions, legislative documents through which civic and religious education were introduced, the national curriculum for civic education, Serbian media reports (predominantly newspaper articles) on the introduction of civic education, as well as transcripts of parliamentary debates about the introduction of electives and the wider reform.

Interview and documentary data were treated like policy artifacts, following the policy-as-discourse theorization (see Ball 1993; Bacchi 2000), and used to (re) construct the discourse at the time. Using the concepts of linguistic and symbolic capital developed by Bourdieu (1991), and ideological-discursive formation, a concept I coined to signify linguistic expressions of ideology in speech and text, a discursive resource that, when used in exchange for other kinds of capital, such as economic or political functions as discursive capital, I analyzed the construction and use of the civic education policy within different fields, that of education, culture, politics, and on different scales, national, international, and transnational. The analysis involved identifying themes and categories, similarly to traditional content analysis, and focusing within them on linguistic categories-words, phrases, clauses, syntax - and using these constructs to theorize the discursive behavior of the different policy actors, their alliances and conflicts, as well as the movement and transformation of the policy and its meaning across different fields.

\section{The (Re)Construction of the Civic Education Policy Discourse}

The analysis of data brought up different policyspeaks across both the national and transnational policyscapes. "Policyspeaks" (parallel to doublespeak or even triplespeak) is a term used by Steiner-Khamsi (2014) and Halász (2012) to describe a phenomenon engaged in by post-communist policymakers when speaking to different audiences, for example national and international ones. Serbian civic education policy was not a singular piece of prescribed norms and action-policies seldom are, although in most cases the message that is sent is presumed to be consistent across media, and in fields in which it is received. In the case of this policy, in the curriculum guidelines and the principles that prescribed pedagogic practice and widely organized teacher training, it may have appeared as straightforward and consistent. This was education that was supposed to help move forward a "modern, European, multi-ethnic society" and the processes of "democratization and European integration" of the Serbian society (Ministry of Education and Sport of Republic of Serbia 2002). However, 
in the policy actors' interactions, conflicts, and alliances, within different spaces and in different ways in which it was used as discursive capital, my analysis made a distinction between multiple versions-hence, "policyspeaks."

The construction of the various aspects of the policy discourse-i.e. various "speaks" - took place within and across different fields. On one hand, there was a distinction between national, regional, and transnational, or supranational fields that was particularly relevant for the sociological construction of the relationships of power, agency, and influence between the nation-state and international organizations and foreign governments in this theorization of a post-communist educational reform. On the other hand, there were fields constructed in a Bourdieusian sense, in which different types of discourseseconomic, cultural, political-were produced, and interacted with the educational field. The way that I used my analytical tools allowed me to create the narrative of a multidimensional policy discourse by looking at the intersection of scalar and discursive fields. In the first instance, relying in particular on my interview data, I mapped out the actors' distribution across different fields and then looked at how they molded the policy, formed alliances and animosities, and derived and created meaning by drawing on different discursive resources from the political, cultural, and economic fields. Their discursive formations that betrayed (or sometimes constructed) the actors' ideological narrative (with lowercase "i") which were variously used as discursive capital drew on democracy, ethnicity, science, patriotism, religion, economy, and international relations. The national field consisted primarily of educational policymakers, educational practitioners, politicians, media, parents, and students. The regional field also included the policymakers, educational practitioners, and third sector organizations from neighboring, ex-Yugoslavian, or ex-communist countries. Finally, the international field of policy influence involved members of international organizations and international NGOs-primarily the Council of Europe, UNESCO, as well as NGOs dedicated to civic education (particularly a prominent UK organization), from whom advice on curriculum development was sought.

Next level analysis involved organizing these actors into "inner circle policy actors," "outer circle policy actors," and "commentators and critics," based on the level of influence on policymaking. The first category included key national policymakers: senior ministry figures and members of the EDC expert group, curriculum developers and national actors in correspondence with the Council of Europe's program. The second group involved advisors and collaborators, including members of the Civil Society ${ }^{3} \mathrm{NGO}$, the Belgrade office of Council of Europe, regional partners, and the Open Society Foundation, a donor organization that had been very active in the area of post-communist education reform, first in Europe and later predominantly Central Asia. The latter group also involved, although in a fairly limited capacity, the members of the public and educational practitioners who, albeit necessarily constructed as the recipients of 
the policy, also had the possibility of participating in the wider reform discourse through various conferences and consultations that were organized during the early days of the reform. Finally, "commentators and critics" included those actors who constructed an "alternative" discourse, excluded from the primary decisionmaking, but present in the policy discourse through the embodiment of the Other, the undesirable ideological-discursive narratives that the civic education policy had tried to negate: right wing members of the shadow cabinet, religious education policy lobbyists and curriculum developers, and the most prominent critics of the reform.

Going between the interview narratives and the different documentary artifacts of the policy discourse (official policy documents, parliamentary debates, media reports) allowed me to make a distinction between the following aspects of the policy discourse, or the following "policyspeaks":

a) Official: constructed primarily in policy documents and Serbian policymakers' engagement with international partners (recounted in interview narratives);

b) Public: constructed in media and parliamentary debates;

c) Political: constructed in individual, unofficial interactions between actors outside of the field of education, and recounted in interview narratives and some media documents;

d) Personal: constructed in sometimes official, occasionally unofficial, interactions, between actors belonging to the educational field, and recounted in interviews.

These policyspeaks were porous and communicated with one another, but the final one is particularly pertinent in the context of this article. It is here where the individual agency and local experience in shaping educational decisions prominently acted contra the agendas and processes in which educational decisions were used as legitimizing devices, signals of virtuous behavior, or political capital.

For example, in the official policyspeak, Serbian civic education policy clearly appeared as an aspect of the global, and, specifically, Europe-wide drive towards instituting education for democratic citizenship into national curricula in order to fight political apathy and xenophobia. With it, Serbian policymakers could signal that they were on the same path as other post-communist countries, confirmed their "return" to Europe and their dedication to European values, and, by using the appropriate ideological-discursive resource (with significant similarity between Serbian and international education for democratic citizenship documents), aligned themselves with international actors and profited from their support and resources. Indeed, if one was analyzing the policy solely within this aspect, one would inevitably have to conclude on the somewhat pessimistic 
note about the powerlessness of small and new states before the demands and dictates of international organizations and the agendas of the Western countries who shape them, or at the very least make a more cynical observation about the "powerless" countries' opportunism.

The public policyspeak primarily took place within the national field, and, therein, policy could have again been said to have been used as a signalling device, but with discursive resources drawing less on the field of education and more on the field of political ideology. With this new subject-and it variously appeared across the public sphere as education for democracy, democratic upbringing, or even education in humanities-policymakers could demonstrate the holy trinity of the reform (democratization, Europeanization, modernization) to the part of the Serbian electorate eager for a democratic change at all levels of society. Particularly in combination with religious education (and the two often featured together in the public sphere) of which it appeared a discursive polar opposite, it served to demonstrate that Serbia's idea of democracy assumed an anti-religious, or at least a non-religious, concept of citizenship, leaving the dangerous discourses of religious nationalism and traditionalism behind. Finally, studied exclusively within the political policyspeak, it was apparently no more than a bargaining chip, used to assuage the concerns about the (re)introduction of the religious education into public schools in the post-war context, or even an attempt, as hypothesized by Bacevic (2005) for example, to appeal to both the progressive and the conservative strands of Serbian society.

In all these three policyspeaks, civic education discourse was constructed in fields external to education, and these external fields necessarily created the conditions and the wider context in which the subject was developed. But this does not mean that this wider context entirely determined the form of civic education. Within the conditions given, Serbian educators worked with what for them was a matter of strong personal and professional conviction rather than convenience: "Here was a chance to make a contribution, to mobilize the education system...I knew what the 1990s did to us, and I knew I had to accept this post if I was to cast out any remains of that period" (Interview with senior Ministry actor, Belgrade, May 2012).

The core of one of the six thematic education working groups in charge of the democratization of education and education for democratic citizenship was formed from the team of psychologists and pedagogues who had spent the 1980s preparing for a post-communist reform and the 1990s developing and delivering various peace education programs, and for whom the idea of citizenship to be fostered through this new subject necessarily had to incorporate mutuality, communication, emotional expression, and conflict management and resolution. It was clear in the processes of the subject development that these concepts bore more weight than the more overtly political-and more common in the context of post-communist civic education-development of self as an active citizen 
or political animal. This contrast is expressed by the head of the Civil Society NGO who had at the time been part of the team working on the content of and the pedagogy for the Serbian civic education, and who took over providing the resources and training for the subject in 2003, after the change of government:

So the reform came down to the psychologization of the whole...of civic education, which is, I mean, when it comes to communication and social skills up until say year four, it is OK, after that, it demands a different kind of knowledge...So you have a certain kind of maturation with those young people, as a result of the knowledge that they acquire, the confidence that they acquire, and a different kind of relationship towards institutions that is built in this way...so we [later] developed these trainings, these teacher trainings, we assisted the Ministry, as we got some funding from the [U.S.] State Department, and if we had not had that funding, we would not have been able to do it. And nobody would have done it. Because it's... a cause for worry. Because in our public system there is no desire to enable citizens to be be active citizens and function in a democratic setting (Interview with head of the Civil Society NGO, Belgrade, June 2012).

On the other hand, 2001-2003 curriculum developers saw their efforts as the necessary work on creating conditions under which students' experiences would be developed in, and thus contribute to the context of non-violence recognized as the primary prerequisite for democracy.

Well the accent was...you see, we as a society don't have a developed civic consciousness, or an understanding of democracy, so...we went for this option, for pragmatic reasons as well... with using the peace education and non-violent communication. We wanted for it to introduce a civil, a civic, approach to life (Interview with a senior EDC team member, Belgrade, February 2012).

But the focus was on the post-war context, on communication, non-violence, acceptance of diversity... and it was unnatural for our context for the national element to be present in civic education because civic education was imagined as education for co-operation (Interview with civic education curriculum developer, Belgrade, February 2012).

The curriculum developers recounted that it was not their intention to completely omit the references to nation and religion, but they believed that in the post-war context it was more important to focus on building mutuality and community on different terms, until such time when conditions for discussing and constructing the nation were themselves less volatile.

This softer, "psychologised" version of civic education was still a political one. Antinationalism is in itself political, and such a version of citizenship that renounces the national and the religious did create political adherents as well as adversaries in Serbia. During the 1990s, when the peace education programs 
that would become the basis for civic education after 2000 were piloted, this was conducted in an atmosphere of fear of the authoritarian regime whose authority of violent nationalism was being challenged through these courses. "We were terrified the whole time, feeling that they could bust in at any time and shut everything down... and schools were afraid to let us in [but] sometimes the headmasters would secretly let us try out some of our workshops" (Interview with civic education curriculum developer, Belgrade, February 2012). Furthermore, the educators were aware of the activist, subversive nature of their work: "Our work, what we did, to us it was some sort of activism, it was a resistance movement" (Interview with civic education curriculum developer, Belgrade, February 2012).

In the end, the version of citizenship they were creating was not ideologically neutral-it hardly ever is. Those 1990s peace programs were, after all, primarily funded by United Nations Children's Fund (UNICEF), however much they may have built on was developed at Belgrade University, so it is perhaps unsurprising that there is significant similarity between the early Serbian version of civic education, before civil society took over with the change of government in Serbia in 2003, and the current UNESCO discourse of global citizenship based on the notions of human rights, multicultural co-existence, and responsible and responsive participation in a trans/post-national society (UNESCO 2015a; 2015b).

\section{Citizenship Education as Education for Peace}

Few instances of educational policymaking at a national level in a globalized world happen without the significant influence of regional and global international agendas and associated expectations and pressures that are often originating in economic and political fields with which the educational field is closely connected. As indicated earlier in the article, the mechanisms of influence, or even control, depend on national economic and political power, or the "national capital" (Ozga 2006), so in the case of European post-communist countries in the 1990s, or indeed across the "third world," where a lot of educational reconstruction has depended on foreign loans, the degree to which the influence on national decisions in education is exercised leaves the nationstate in a position of relative powerlessness. That is not to say, of course, that educational policy decisions equal educational practice, and the latter does not necessarily follow in the way envisaged by the (inter)national policy elite. What this article has hopefully demonstrated is that at a certain level of analysis, even before getting to the educational practice, policymaking itself can be marked by a substantial exercise of agency on the part of national policymakers, albeit perhaps not across all aspects of the policy discourse and all policyspeaks. 
Thus, whilst policyspeaks confined to the fields of economy, national, and international politics used civic education as discursive capital for different kinds of gain, where educational decisions on curriculum design and teacher training transcended the flags of convenience that were policy documents and political speeches, national decision-makers were the ones in control. This is testified both by the final outcomes that incorporated originally developed work on peace education during the 1990s and the educational theory and practice developed at Belgrade University decades earlier and partly sustained through NGO work during the unfavorable conditions of the 1990s when educators were often in conflict with the government (Djerasimovic and Maksimovic 2017). The national policymakers' agency is also indicated by their and their foreign advisors' reports of the extraordinary sense of preparedness with which they entered the reform, the latter even eventuating in a certain sense of pride or almost arrogance in noting the advanced state of their work in comparison with what was being offered by international consultants.

Sometimes they [the Council of Europe] would send us someone, some Czech [who] probably got some licence for this during the 1990s...to come here and, to tell you the truth, it was like trying to teach your grandmother to suck eggs... we were so much further ahead than they were. So there was quite a lot of time-wasting in those situations (Interview with EDC team member, Belgrade, May 2012).

This was partly due to the belated nature of the reform that allowed both the time to prepare and the opportunity to learn from others' success and failures: "I wanted for Serbia not to go in the known wrong direction. Maybe we would have gone in an unknown one, but at least we did not have to go in the direction we knew was wrong" (Interview with senior Ministry actor, Belgrade, May 2012).

But there was little doubt that when it came to civic education, the Serbian EDC team had a fairly clear idea of what they wanted and what they thought Serbian society needed the most at that point in terms of creating conditions for democracy to develop, as noted by a member of a UK civic education NGO:

I think I remember probably two visits to London of this group, and I have to say that we were very impressed by them! They were, um, I think we said in this evaluation, they were most advanced in their thinking than any of the central and eastern European countries that we had visited (Interview with UK civic education NGO, London, October 2012).

One purpose of this article then has been to demonstrate that the concept of glocalisation (Bain 2010; Jahng 2011) in educational policymaking ought to take into account the agency of the national policymakers, and in a way that goes beyond recognizing the adroitness of the latter at using the policy discourse for achieving political and economic ends. In some of its aspects, educational policy 
discourse can reflect a significant level of self-referentiality (Schriewer 2003) and the important role that the local knowledge and experience of educational matters can play in the context of unequal power relationship.

Secondly, this reflection on the Serbian experience of creating civic education within the condition of building democracy in the post-war context points both to a high level of malleability and porousness between civic and peace education, and the need to re-examine their overt distinction, particularly where the contextual emphasis on the political knowledge within the national context obscures the wider global and extra-national construction of community and responsibility (see Djerasimovic (2018) for observation on Britishness-however multiculturally constructed-as the dominant, national axis of citizenship in English civic education).

On a transnational scale, this conceptual integration is evident in the extreme similarity between, on one hand, UNESCO's 1970s-1990s peace education discourse with its emphasis on non-violence, human rights, dialogue and cooperation, fostered within the democratic conditions of tolerance of diversity and multicultural understanding and an active participation of all members of society on achieving it (Rosandic 2000), and, on the other, the contemporary global citizenship education agenda:

Global citizenship education aims to be transformative, building the knowledge, skills, values and attitudes that learners need to be able to contribute to a more inclusive, just and peaceful world. Global citizenship education takes 'a multifaceted approach, employing concepts and methodologies already applied in other areas, including human rights education, peace education, education for sustainable development and education for international understanding' and aims to advance their common objectives (UNESCO 2015a).

Finally, in the literature, the combination of civic and peace education discourses appears in theorizations on democratic peace (Ericson 2000), forms of peace education that incorporate to a different degree most of the global citizenship education discourse (Harris 2004), and positive peace that is achieved through the absence of structural violence (Galtung 2011). Positive peace takes into account the conditions of economic and political oppression and inequality - the link to active, conscious, equal civic participation, rights, and responsibilities is clear-and the understanding that a peaceful world to aspire to is one that eliminates the culture of war through global citizenship education that teaches "living with justice and compassion; building intercultural respect, reconciliation, and solidarity; promotion of human rights and responsibilities; living in harmony with the earth; and cultivating inner peace" (Toh and Kawagas 2017, 534). 


\section{Conclusion}

Through recounting the introduction and construction of civic education in the post-authoritarian, post-war Serbia, this article interrogated various levels of influence and discursive positioning inherent in policy production in the late modern world. Previous pages served to challenge the occasionally simplified notions of policy/discourse transfer and policy imposition in the conditions of political and economic inequality on a global stage, and underlined the importance of local knowledge and the various uses of discursive resources held by national policymakers. It is important to add that, whilst the ideas of citizenship as constructed within different fields-political, cultural, religiousand the conceptual proximity of supranational citizenship and peace education programs were noted, the article has not given due consideration-as the focus was elsewhere-to the normative assumptions and cultural legacies shaping the idea of democracy and peace that are shared between Serbian and Western conceptions. In this, the Serbian case of the use of discursive capital by national policymakers in the international field is perhaps not as representative of other contexts where the conflict between the national and international discourses may be more pronounced and interlinked with much deeper structural and historical inequality in power relations, such as is the subject of critical (peace) education that indeed fosters the recognition of the occasional necessity and benefit of conflict (see Zembylas and Bekerman 2013).

Finally, there is a danger whenever one is analyzing policy that the attention given to the politics, or even semiotics, of policy development obscures the realities of educational practice. Multiple studies on the effects of civic education-whether on political attitudes and participation, or ethnic distance and authoritarianism-conducted over the years, in Serbia as well as elsewhere (see Torney-Purta et al. 2001; Kahne, Chi, and Middaugh 2006; DžamonjaIgnjatović, Baucal, and Radić-Dudić 2009; Vasiljevic 2009; Finkel, Horowitz, and Rojo-Mendoza 2012), were inconclusive on its effects. Whatever the conclusions about the potential for national-level educational policymaking to reflect contextdependent needs and issues, more study is needed around the space and resources given to the practitioners to deliver these programs and the potential of the latter to achieve cohesion and peace, particularly in educational systems increasingly oriented and normatively conditioned towards performance, comparison, and competition.

\section{Notes}

1. The author recognizes the risks of oversimplification inherent in using a West/East dichotomy, and notes the utilization of "Western" here as a heuristic device to denote 
the so-called "first world" in the context in which international political and economic relations following the end of communism in Europe bear significantly on the making of educational decisions in "Eastern" countries post-1989.

2. Also see Lynch (1998) on the similar concept of "flags of convenience."

3. The name is a pseudonym for a Belgrade-based NGO whose primary mandate is to support and assist with the development of civil society in Serbia. After the change of government in 2003, they have been heavily involved in delivering resources and teacher training for civic education.

\section{References}

Bacchi, Carol. 2000. "Policy as discourse: What does it mean? Where does it get us?" Discourse: Studies in the Cultural Politics of Education 21 (1): 45-55.

Bacevic, Jana. 2005. "Veronauka i(li) evronauka - kritika elemenata reforme obrazovanja 2000-2003" [Religious education and/or Euroeducation - a critique of some elements of the 2000-2003 education reform]. Glasnik Etnografskog instituta SANU [Herald of the SANU Institute of Ethnography] 53: 171-183.

Bain, Olga. 2010. "Education after the fall of the Berlin Wall: The end of history or the beginning of histories?" In Post-socialism Is Not Dead: (Re)reading the Global in Comparative Education, ed. Iveta Silova, 28-57. Bingley: Emerald Books.

Ball, Stephen J. 1993. "What is policy? Texts, trajectories and toolboxes." Discourse: Studies in the Cultural Politics of Education 13 (2): 10-17.

Džamonja-Ignjatović, Tamara, Aleksandar Baucal, and Radmila Radić-Dudić. 2009. "Civil education in elementary and secondary schools in Serbia: Evaluation study." Godišnjak Fakulteta Političkih Nauka [Faculty of Political Science Annual] 3 (3): 71123.

Birzea, Cezar. 1994. Educational Policies of the Countries in Transition. Strasbourg: Council of Europe Press.

Birzea, Cezar. 1996. "Educational reform and power struggles in Romania." European Journal of Education 31 (1): 97-107.

Birzea, Cezar. 2004. All-European Study on Education for Democratic Citizenship Policies. Strasbourg: Council of Europe Publishing.

Blokker, Paul. 2005. "Post-communist modernization, transition studies, and diversity in Europe." European Journal of Social Theory 8 (4): 503-525.

Buk-Berge, Elisabeth. 2006. "Missed opportunities: The IEA's study of civic education and civic education in post-communist countries." Comparative Education 42 (4): 533548.

Bourdieu, Pierre. 1991. Language and Symbolic Power. Cambridge: Polity Press.

Carothers, Thomas. 2009. "Democracy assistance: Political vs. developmental?" Journal of Democracy 20 (1): 5-19.

Corovic, Vladimir. 2004. Istorija Srba [History of the Serbian People]. Beograd: Logos Art.

Crick, Bernard. 2007. "Citizenship: The political and the democratic." British Journal of Educational Studies 55 (3): 235-248.

Dahlin, Bo. 2010. "A state-independent education for citizenship? Comparing beliefs and values related to civic and moral issues among students in Swedish mainstream and 
Steiner Waldorf schools." Journal of Beliefs \& Values 31 (2): 165-180.

Djerasimovic, Sanja. 2018. "A $21^{\text {st }}$ century European citizen: Construction of the Serbian civic education discourse and its comparison with England." In Comparing PostSocialist Transformations: Education in Eastern Europe and Former Soviet Union, eds. Iveta Silova, and Maia Chankseliani. Oxford: Symposium Books.

Djerasimovic, Sanja, and Maja Maksimovic. 2017. “Becoming European.” In Adult Education and Lifelong Learning in Southeastern Europe, eds. George A. Koulaouzides, and Katarina Popović, 115-130. Rotterdam: Sense Publishers.

Duerr, Karlheinz. 2000. Strategies for Learning Democratic Citizenship. Strasbourg: Council of Europe.

Ericson, Magnus. 2000. "Birds of a feather? On the intersections of stable peace and democratic research programs.” In Stable Peace among Nations, eds. Arie M. Kacowicz, Yaacov bar-Siman-Tor, Ole Elgström, and Magnus Jerneck. Lanham: Rowman \& Littlefield Publishers.

Finkel, Steven E., Jeremy Horowitz, and Reynaldo T. Rojo-Mendoza. 2012. "Civic education and democratic backsliding in the wake of Kenyas post-2007 election violence." The Journal of Politics 74 (1): 52-65.

Forrester, Keith. 2003. "Leaving the academic towers: The Council of Europe and the education for democratic citizenship project." International Journal of Lifelong Education 22 (3): 221-234.

Galtung, Johan. 2011. "Peace, positive and negative." In The Encyclopedia of Peace Psychology, ed. Daniel J. Christie. West Sussex: Blackwell Publishing Ltd.

Halász, Gábor. 2012. "Policy cultures and education policy: A Central and Eastern European perspective." In Educational Policy in an International Context: Political Culture and Its Effects, eds. Karen Seashore Louis, and Boudewijn van Velzen, 213222. New York: Palgrave Macmillan.

Harris, Ian M. 2004. "Peace education theory." Journal of Peace Education 1 (1): 5-20.

Jahng, Kyung Eun. 2011. "Glocalisation or globalisation? Travelling discourses of child poverty policy in South Korea." Globalisation, Societies and Education 9 (3-4): 457471.

Kahne, Joseph, Bernadette Chi, and Ellen Middaugh. 2006. "Building social capital for civic and political engagement: The potential of high-school civics courses." Canadian Journal of Education / Revue Canadienne de Léducation 29 (2): 387-409.

King, Charles. 2000. "Post-postcommunism: Transition, comparison, and the end of 'Eastern Europe." World Politics 53 (1): 143-172.

Klees, Stephen. 2002. "World Bank education policy: New rhetoric, old ideology." International Journal of Educational Development 22: 451-474.

Levinson, Meira. 2014. "Citizenship and civic education." In Encyclopedia of Educational Theory and Philosophy, ed. D. C. Phillips. Thousand Oaks, CA: Sage.

Levitsky, Steven, and Lucan Way. 2005. "International linkage and democratization." Journal of Democracy 16 (3): 20-34.

Lynch, J. 1998. "The international transfer of dysfunctional paradigms." In Learning and teaching in an international context: research, theory and practice, eds. David Johnson, Bob Smith, and Michael Crossley, 7-34. Bristol: Centre for International Studies.

McLaughlin, T. H. 1992. "Citizenship, diversity and education: A philosophical perspective." Journal of Moral Education 21 (3): 235-250. 
McLeish, Elizabeth A., and David Phillips, eds. 1998. Processes of Transition in Educational System: Oxford Studies in Comparative Education. Wallingford: Symposium Books.

Ministry of Education and Sport Republic of Serbia. 2002. Quality Education for All: A Way toward a Developed Society. Belgrade: Ministry of Education and Sport Republic of Serbia.

Mungiu-Pippidi, Alina. 2006. "Democratization without decommunization in the Balkans." Orbis 50 (4): 641-655.

Nicoll, Katherine, Andreas Fejes, Maria Olson, Magnus Dahlstedt, and Gert Biesta. 2013. "Opening discourses of citizenship education: A theorization with Foucault." Journal of Education Policy 28 (6): 828-846.

Offe, Carl. 1991. "Capitalism by democratic design? Facing triple transition in East Central Europe." Social Research 58 (4): 866-892.

Ozga, Jennifer. 2006. "Globalisation, education policy and politics." In The Routledge Reader in Education Policy and Politics, eds. Jenny Ozga, and Robert Lingard. London: Routledge.

Perry, Laura B. 2012. "Democratic aspects of communist and post-communist schooling in Central and Eastern Europe." In Logics of Socialist Education, eds. Tom G. Griffiths, and Zsuzsa Millei, 155-171. Dordrecht: Springer.

Rosandic, Ružica. 2000. “Grappling with peace education in Serbia.” Peace works No. 33, United State Institute for Peace, April 1. https://www.usip.org/publications/2000/04/ grappling-peace-education-serbia (accessed April 30, 2018).

Silova, Iveta, ed. 2010. Post-socialism Is Not Dead: (Re)reading the Global in Comparative Education. Bingley: Emerald Books.

Silova, Iveta, and Gita Steiner-Khamsi, eds. 2008. How NGOs React: Globalisation and Education Reform in the Caucasus, Central Asia and Mongolia. Bloomfield: Kumarian Press.

Schriewer, Jürgen. 2003. "Globalisation in education: Process and discourse." Policy Futures in Education 1 (2): 271-283.

Steiner-Khamsi, Gita. 2014. "Cross-national policy borrowing: Understanding reception and translation." Asia Pacific Journal of Education 34 (2): 153-167.

Steiner-Khamsi, Gita, and Hubert O. Quist. 2000. "The politics of educational borrowing: Reopening the case of Achimota in British Ghana." Comparative Education Review 44 (3): 272-299.

Steiner-Khamsi, Gita, Judith Torney-Purta, and John Schwille. 2002. New Paradigms and Recurring Paradoxes in Education for Citizenship: An International Comparison. Oxford: Elsevier Science.

Toh, Swee-Hin, and Virginia Cawagas. 2017. "Building a culture of peace through global citizenship education: An enriched approach to peace education." Childhood Education 93 (6): 533-537.

Torney-Purta, Judith, John Schwille, and Jo-Ann Amadeo. 1999. Civic Education across Countries: Twenty-Four National Case Studies from the IEA Civic Education Project. Amsterdam: IEA Secretariat.

Turnbull, Jacquie. 2002. "Values in educating for citizenship: Sources, influences and assessment." Pedagogy, Culture \& Society 10 (1): 123-134.

UNESCO (United Nations Education, Scientific and Cultural Organization). 2015a. Global Citizenship Education: Topics and Learning Objectives. Paris: UNESCO. 
UNESCO (United Nations Education, Scientific and Cultural Organization). 2015b. Education 2030 Incheon Declaration: Towards Inclusive and Equitable Education and Lifelong Learning for All. Paris: UNESCO.

Vaillant, Janet G. 2001. "Civic education for Russia: An outsider's view." In Education and Civic Culture in Post-Communist Countries, eds. Stephen Webber, and Ilkka Liikanen, 260-272. London: Palgrave Macmillan.

Vasiljevic, Branka. 2009. "Civic education as a potential for developing civil society and democracy: (The Case of Serbia).” Master diss., University of Tromsø.

Zembylas, Michalinos, and Zvi Bekerman. 2013. "Peace education in the present:

Dismantling and reconstructing some fundamental theoretical premises." Journal of Peace Education 10 (2): 197-214.

Sanja Djerasimovic is Research Fellow at the University of Exeter, UK. She completed her DPhil in Education at the University of Oxford on the subject of civic education policy introduction in the context of post-2000 Serbia. She has published on civic education, policymaking in the postcommunist context, and the ethics and the use of discourse analysis in educational research. Her current research is focused on the higher education policy, research evaluation and use, and the idea of (academic) citizenship. Email: s.djerasimovic@exeter.ac.uk 